\title{
Comparative morphology and morphometric analysis of some Histeridae (Insecta: Coleoptera) species
}

\author{
Cansu KILIÇ ${ }^{1}$, Ferhat ALTUNSOY ${ }^{* 1}$ \\ ORCID: 0000-0002-7969-7394; 0000-0002-4446-323X
}

${ }^{1}$ Eskişehir Technical University, Faculty of Science, Department of Biology, 26000, Eskişehir, Turkey

\begin{abstract}
Histeridae (Coleoptera) is a worldwide group of about 400 genera and 4500 species. Many family members are predators of eggs, larvae, and adults of Diptera (Insecta) species. On the other hand, rotting corpses have great precaution in forensic studies due to their feeding and colonization. The taxonomic characters used in the classification of Histeridae species are based on morphology. However, the variations in morphological characters cause difficulties in the determinations that lead to significant errors in the diagnostic process. In this study, seasonal variations of some Histeridae species used to determine the minimum time of death (PMI) in forensic investigations are evaluated with geometrical morphometry and the references given for the prevention of errors for identifying species.
\end{abstract}

Keywords: Histeridae, morphometry, Taxonomic character, Coleoptera, PMI

\section{Bazı Histeridae (Insecta: Coleoptera) türlerinin karşılaştırmalı morfolojisi ve morfometrik analizi}

\section{Özet}

Histeridae (Coleoptera) dünya çapında yaklaşık 400 cins ve 4500 tür ile temsil edilen bir gruptur. Birçok Familya üyesi Diptera (Insecta) türlerinin yumurta, larva ve erginleri üzerinde predatördür. Diğer taraftan çürüyen cesetler üzerinde beslenmeleri ve kolonizasyonları sayesinde adli çalışmalarda büyük öneme sahiptir. Histeridae türlerinin sınıflandırılmasında kullanılan taksonomik karakterler morfoloji temellidir. Ancak morfolojik karakterlerdeki varyasyonlar teşhis aşamasında önemli hatalara neden olduğundan tayinlerde zorluk çıkarmaktadır. Bu çalışmada adli araştırmalarda minimum ölüm zamanının (PMI) belirlenmesi amacıyla kullanılan bazı Histeridae türlerinin ceset üzerindeki mevsimsel süksesyonuna bağlı olarak ortaya çıkan varyasyonları, geometrik morfometrik analizlerle ortaya koyulmuş ve türlerin teşhisinde yapılabilecek hataların önlenmesi için referans veriler sunulmuştur.

Anahtar kelimeler: Histeridae, morfometri, Taksonomik karakter, Coleoptera, PMI

\section{Introduction}

Histeridae (Clown beetles) belong to the Coleoptera order, including 400 genera and 4500 species [1, 2, 3, 4]. The majority of the Histerids are predators by feeding on the adult, larvae, and eggs of the Diptera species. The species of the Histeridae are also used as control agents on some of the other insect groups that are both harmful to agriculture and livestock [5,6]. It was observed that the many Histerid adults and larvae are necrophilous and play a significant role in forensic investigations by feeding other Diptera larvae during the active decay and early advanced decay stages $[7,8,9]$, also stated that Histerids are the most abundant Coleoptera species attracting to carcass after Staphylinidae.

Identification of the species accurately is crucial in forensic investigations. In previous studies, it has been studied on the forensically essential species of the Histaridae [10,9]. The main problem in these studies was the specific identification of species, especially of the genus Saprinus. Considering the identification keys, taxonomic characters can not clearly distinguish the morphological structures of the species [11, 12]. According to Krikken \&

\footnotetext{
* Corresponding author / Haberleşmeden sorumlu yazar: Tel.: +902223213550/4710; Fax.: +902223204910; E-mail: tabanidae@ msn.com

(C) Copyright 2021 by Biological Diversity and Conservation $\quad$ Received: 06.08.2021; $\quad$ Published: 15.12.2021
} 
Huijbregts, [13], the reason for intensive use of other necrophilous insects in forensic practices rather than Coleoptera is probably because of their taxonomic inconvenience. In consequence of variations on the specimens depending on seasonal and periodical impact, the area on which they were fed on the corpse, and the altitude, the characters presented in the keys were often referred to by using the terms 'less-than' or by comparing them to one another [12, 14]. These variations probably cause differences in the morphological characters and complicate to use of identification keys. This study aims to evaluate the variations with morphometric analyses and contribute to the keys for diagnosing the species. For this purpose variations in the morphological characters of the four species of Saprinus genus, Saprinus caerulescens, S. semistiratus, S. planiusculus, and S. Subnitescens, have been determined by statistical methods, for allowing accurate identifying of the species.

\section{Materials and methods}

This study examined the four species belonging to the Histeridae family, the Saprinus genus: Saprinus caerulescens, S. semistiratus, S. planiusculus, and S. subnitescens. Adult specimens were collected on the pig carcasses in Tandır Village, Eskişehir province, Turkey (Lat.: 39,92159 ${ }^{\circ}$, Long.: 30,69099 ${ }^{\circ}$, Elev.: 1280 meter) and were transferred to the laboratory. This area has been specially selected because it remains between the Sakarya valley, which is seen as a Mediterranean climate, and the land climates. Specimens were identified according to keys by Secchi, [12] and Lackner, [11]. Twenty male specimens, known to have variations, were selected. First of all, for morphological comparing genitalia Six biometric characters determined by Ohara, [15], APW width between anterior angles of pronotum; EL length of elytron along the sutural line; EW maximal width between outer margins of elytra; PEL length between anterior angles of pronotum and apices of elytra; PPW width between posterior angles of pronotum and PW maximal width of propygidium were selected and compared as morphologically and morphometrically. Photographs of these six characters were taken with Canon D90 (Canon Zoom Lens EF 55-200mm) and measurements acquired by the ImageJ. The measurements were then evaluated with SPSS (IBM SPSS statistic 24). ANOVA tests were applied to assessments for displaying variations.

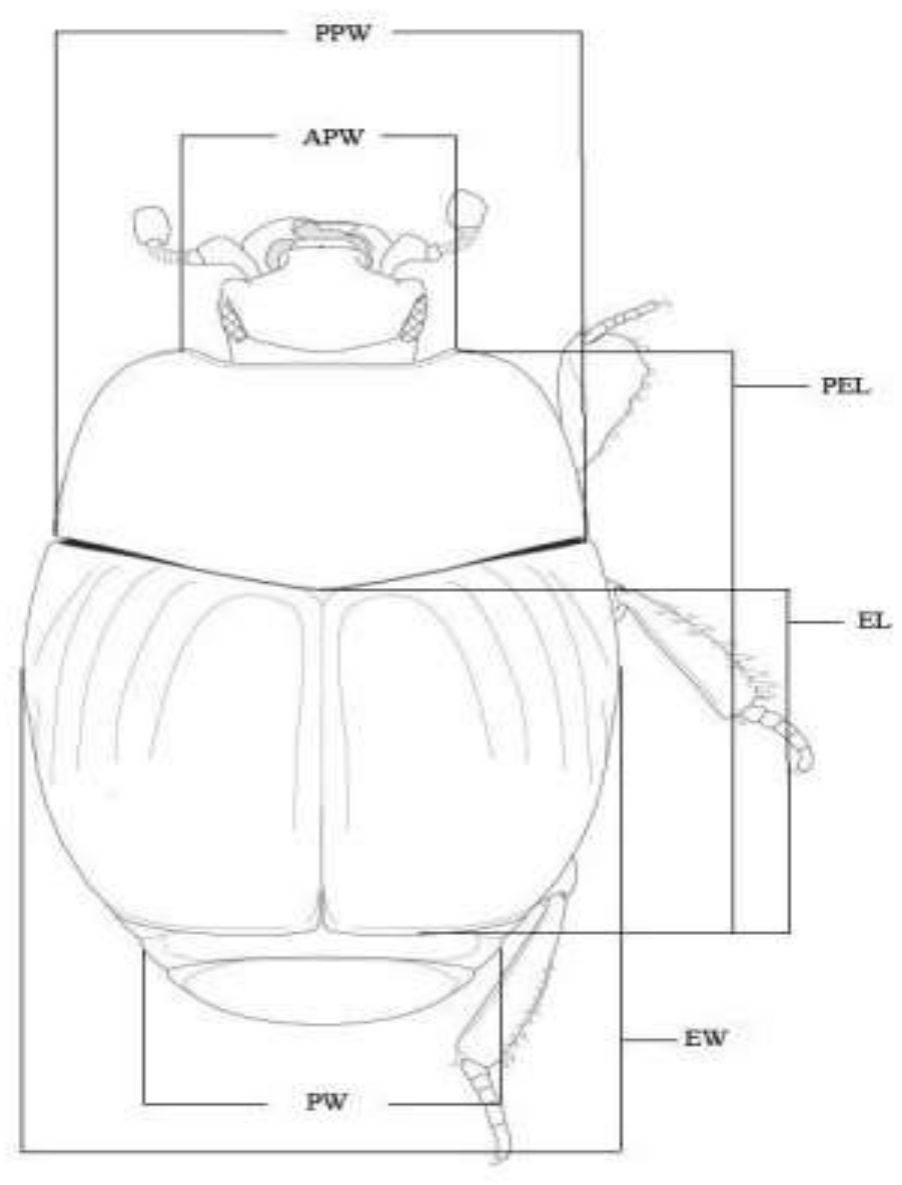

Figure 1. Biometric characters of Saprinus: APW width between anterior angles of pronotum; EL length of elytron along the sutural line; EW maximal width between outer margins of elytra; PEL length between anterior angles of pronotum and apices of elytra; PPW width between posterior angles of pronotum and PW maximal width of propygidium 


\section{Results and discussion}

The statistical analyses achieved after the morphometric measurements of the six characters show that the method we used can be used reliably to identify the species. Remarkably, the six characters, whose measurements were made, within each species were examined. According to the ANOVA test, statistical differences were found between the measurements of these biometric characters for all species $(\mathrm{P}<0,05)$ (Table 1).

\begin{tabular}{|c|c|c|c|c|c|c|}
\hline \begin{tabular}{|l} 
Table 1 \\
Species
\end{tabular} & \multicolumn{6}{|c|}{ ANOVA } \\
\hline \multicolumn{7}{|c|}{ Saprinus (Saprinus) caerulescens } \\
\hline \multirow{3}{*}{$\overline{\mathrm{APW}}$} & Between Groups &, 555 & 3 &, 185 & 3,993 &, 015 \\
\hline & Within Groups & 1,667 & 36 &, 046 & & \\
\hline & Total & 2,222 & 39 & & & \\
\hline \multirow[t]{3}{*}{ PPW } & Between Groups & 2,838 & 3 & ,946 & 4,204 &, 012 \\
\hline & Within Groups & 8,101 & 36 &, 225 & & \\
\hline & Total & 10,939 & 39 & & & \\
\hline \multirow[t]{3}{*}{ PEL } & Between Groups & 6,388 & 3 & 2,129 & 7,817 &, 000 \\
\hline & Within Groups & 9,807 & 36 &, 272 & & \\
\hline & Total & 16,195 & 39 & & & \\
\hline \multirow[t]{3}{*}{ EL } & Between Groups & 4,193 & 3 & 1,398 & 7,090 & ,001 \\
\hline & Within Groups & 7,098 & 36 & ,197 & & \\
\hline & Total & 11,291 & 39 & & & \\
\hline \multirow[t]{3}{*}{ EW } & Between Groups & 2,134 & 3 & ,711 & 3,191 & 035 \\
\hline & Within Groups & 8,024 & 36 &, 223 & & \\
\hline & Total & 10,158 & 39 & & & \\
\hline \multirow[t]{3}{*}{ PW } & Between Groups & 1,998 & 3 & ,666 & 4,050 & ,014 \\
\hline & Within Groups & 5,920 & 36 & ,164 & & \\
\hline & Total & 7,918 & 39 & & & \\
\hline \multicolumn{7}{|c|}{ Saprinus (Saprinus) planiusculus (Hoffmann 1803) } \\
\hline \multirow[t]{3}{*}{ APW } & Between Groups &, 339 & 3 & ,113 & 4,430 &, 009 \\
\hline & Within Groups & ,919 & 36 &, 026 & & \\
\hline & Total & 1,259 & 39 & & & \\
\hline \multirow[t]{3}{*}{ PPW } & Between Groups & 1,173 & 3 & ,391 & 4,715 & ,007 \\
\hline & Within Groups & 2,984 & 36 &, 083 & & \\
\hline & Total & 4,157 & 39 & & & \\
\hline \multirow[t]{3}{*}{ PEL } & Between Groups & 1,053 & 3 & ,351 & 2,171 & 050 \\
\hline & Within Groups & 5,824 & 36 & 162 & & \\
\hline & Total & 6,877 & 39 & & & \\
\hline \multirow[t]{3}{*}{ EL } & Between Groups &, 395 & 3 &, 132 & 2,788 &, 044 \\
\hline & Within Groups & 1,699 & 36 &, 047 & & \\
\hline & Total & 2,093 & 39 & & & \\
\hline \multirow[t]{3}{*}{ EW } & Between Groups & 1,800 & 3 & ,600 & 8,148 &, 000 \\
\hline & Within Groups & 2,650 & 36 & ,074 & & \\
\hline & Total & 4,450 & 39 & & & \\
\hline \multirow[t]{3}{*}{ PW } & Between Groups &, 569 & 3 &, 190 & 3,099 & 039 \\
\hline & Within Groups & 2,202 & 36 &, 061 & & \\
\hline & Total & 2,771 & 39 & & & \\
\hline \multicolumn{7}{|c|}{ Saprinus (Saprinus) semistriatus (Scriba, 1790) } \\
\hline \multirow[t]{3}{*}{ APW } & Between Groups &, 510 & 3 &, 170 & 3,026 &, 042 \\
\hline & Within Groups & 2,023 & 36 &, 056 & & \\
\hline & Total & 2,534 & 39 & & & \\
\hline \multirow[t]{3}{*}{ PPW } & Between Groups &, 706 & 3 &, 235 & 3,024 &, 042 \\
\hline & Within Groups & 2,802 & 36 &, 078 & & \\
\hline & Total & 3,508 & 39 & & & \\
\hline PEL & Between Groups & 1,268 & 3 & 4,423 & 2,856 &, 031 \\
\hline
\end{tabular}


Table 1. Continued

\begin{tabular}{|c|c|c|c|c|c|c|}
\hline & Within Groups & 5,329 & 36 &, 148 & & \\
\hline & Total & 6,597 & 39 & & & \\
\hline \multirow[t]{3}{*}{ EL } & Between Groups &, 503 & 3 &, 168 & 2,794 & 044 \\
\hline & Within Groups & 2,162 & 36 &, 060 & & \\
\hline & Total & 2,666 & 39 & & & \\
\hline \multirow[t]{3}{*}{ EW } & Between Groups &, 952 & 3 & 317 & 2,430 & 041 \\
\hline & Within Groups & 4,702 & 36 & 131 & & \\
\hline & Total & 5,654 & 39 & & & \\
\hline \multirow[t]{3}{*}{$\mathrm{PW}$} & Between Groups & 1,022 & 3 &, 341 & 3,340 & 030 \\
\hline & Within Groups & 3,671 & 36 & 102 & & \\
\hline & Total & 4,692 & 39 & & & \\
\hline \multicolumn{7}{|c|}{ Saprinus subnitescens Bickhardt, 1909} \\
\hline \multirow[t]{3}{*}{ APW } & Between Groups & 282 & 3 & ,094 & 3,387 & 028 \\
\hline & Within Groups & 999 & 36 & 028 & & \\
\hline & Total & 1,281 & 39 & & & \\
\hline \multirow[t]{3}{*}{ PPW } & Between Groups & 1,458 & 3 & ,486 & 4,897 &, 006 \\
\hline & Within Groups & 3,573 & 36 & 099 & & \\
\hline & Total & 5,030 & 39 & & & \\
\hline \multirow[t]{3}{*}{ PEL } & Between Groups & 1,288 & 3 & 429 & 2,653 & 063 \\
\hline & Within Groups & 5,826 & 36 &, 162 & & \\
\hline & Total & 7,114 & 39 & & & \\
\hline \multirow[t]{3}{*}{ EL } & Between Groups &, 533 & 3 &, 178 & 3,149 & 037 \\
\hline & Within Groups & 2,030 & 36 & 056 & & \\
\hline & Total & 2,563 & 39 & & & \\
\hline \multirow[t]{3}{*}{ EW } & Between Groups & 1,422 & 3 & ,474 & 3,870 &, 017 \\
\hline & Within Groups & 4,410 & 36 & 123 & & \\
\hline & Total & 5,833 & 39 & & & \\
\hline \multirow[t]{3}{*}{ PW } & Between Groups & 1,900 & 3 & 633 & 9,609 &, 000 \\
\hline & Within Groups & 2,373 & 36 & 066 & & \\
\hline & Total & 4,273 & 39 & & & \\
\hline
\end{tabular}

* According to the data obtained, there is a significant difference between all biometric characters. $(\mathrm{P}<0,05)$

The measurements of each biometric character on twenty individuals were analyzed with the Tukey test (Table 2). Statistically significant differences were found between the results. In this case, it was also determined that the length of each biometric character differs between species and therefore these analyzes can be used safely in species identification.

Table 2. Interspecies comparison of the lengths of biometric parameters

\begin{tabular}{|c|c|c|c|c|}
\hline \begin{tabular}{|l} 
Biometrical \\
Parameters
\end{tabular} & $\begin{array}{l}\text { Lengths }(\mathrm{mm}) \\
\text { Mean } \pm \mathrm{SE}^{*}\end{array}$ & & & \\
\hline & \begin{tabular}{|l} 
Saprinus \\
caerulescens
\end{tabular} & \begin{tabular}{|l} 
Saprinus \\
planiusculus
\end{tabular} & \begin{tabular}{|l|} 
Saprinus \\
semistriatus
\end{tabular} & Saprinus subnitescens \\
\hline $\mathbf{A P W} * *$ & $1,64 \pm 0,03 \mathrm{a}$ & $1,20 \pm 0,02 b$ & $0,95 \pm 0,03 \mathrm{c}$ & $0,99 \pm 0,02 \mathrm{~d}$ \\
\hline PPW** & $4,55 \pm 0,03 \mathrm{a}$ & $3,53 \pm 0,04 b$ & $3,03 \pm 0,03 \mathrm{c}$ & $2,89 \pm 0,04 \mathrm{~d}$ \\
\hline PEL** & $5,73 \pm 0,06 \mathrm{a}$ & $4,41 \pm 0,04 \mathrm{~b}$ & $3,80 \pm 0,03 \mathrm{c}$ & $3,73 \pm 0,02 \mathrm{~d}$ \\
\hline EL** & $3,19 \pm 0,02 \mathrm{a}$ & $2,56 \pm 0,02 b$ & $2,12 \pm 0,03 \mathrm{c}$ & $2,76 \pm 0,06 \mathrm{~d}$ \\
\hline $\mathbf{E W} * *$ & $5,00 \pm 0,03 \mathrm{a}$ & $3,98 \pm 0,03 \mathrm{~b}$ & $3,40 \pm 0,03 \mathrm{c}$ & $3,19 \pm 0,04 \mathrm{~d}$ \\
\hline $\mathbf{P W} * *$ & $3,27 \pm 0,03 \mathrm{a}$ & $2,49 \pm 0,03 \mathrm{~b}$ & $2,10 \pm 0,03 \mathrm{c}$ & $1,88 \pm 0,02 \mathrm{~d}$ \\
\hline
\end{tabular}

$*$ Mean and Standard error values
$* *$ There is a statistically significant difference between the biological parameter data of the species shown with different letters (a-d) in the same row. (Anova, Tukey).

$\mathrm{F}(\mathrm{APW})=3,993 \mathrm{~F}(\mathrm{PPW})=4,204 \mathrm{~F}(\mathrm{PEL})=7,817 \mathrm{~F}(\mathrm{EL})=7,090 \mathrm{~F}(\mathrm{EW})=3,191 \mathrm{~F}(\mathrm{PW})=4,050 \mathrm{df}=3,76 \mathrm{P}<0,05$

Statistically, significant differences were confirmed with the analyzes made between the species. The analyses of each species on the same morphometric character, which is the study's supporting element, is given below (Table 3). 
According to the table; D8, D9, D10, and D11, which are the abbreviations of the sample material, are given as equivalent to June, July, August, and September, respectively, since monthly sampling is done on domestic pigs. Analysis results in the same column in the table include measurements of different species. As shown in Table 3, Saprinus species collected from the same pig sample were statistically different when evaluated in terms of each biometric character.

Table 3. Comparison of measurements of biometric characters within the same species found in different months

\begin{tabular}{|c|c|c|c|c|c|}
\hline \multirow{2}{*}{\multicolumn{2}{|c|}{ APW }} & \multicolumn{4}{|c|}{ MATERIALS } \\
\hline & & D8 & D9 & D10 & D11 \\
\hline \multirow{4}{*}{ 氙 } & $\begin{array}{l}\text { Saprinus } \\
\text { caerulescens }\end{array}$ & $1,76 \pm 0,20 \mathrm{a}$ & $1,64 \pm 0,21 \mathrm{a}$ & $1,76 \pm 0,23 \mathrm{a}$ & $1,47 \pm 0,21 \mathrm{a}$ \\
\hline & $\begin{array}{l}\text { Saprinus } \\
\text { planiusculus }\end{array}$ & $1,30 \pm 0,11 b$ & $1,26 \pm 0,15 b$ & $1,05 \pm 0,16 b c$ & $1,18 \pm 0,20 b$ \\
\hline & Saprinus semistriatus & $0,96 \pm 0,19 \mathrm{c}$ & $1,02 \pm 0,10 \mathrm{c}$ & $0,85 \pm 0,16 b$ & $0,97 \pm 0,18 b c$ \\
\hline & $\begin{array}{l}\text { Saprinus } \\
\text { subnitescens }\end{array}$ & $1,03 \pm 0,26 \mathrm{c}$ & $0,89 \pm 0,09 c$ & $1,09 \pm 0,13 \mathrm{c}$ & $0,90 \pm 0,14 \mathrm{c}$ \\
\hline
\end{tabular}

$\mathrm{F}($ apwd8) $=1,748 \mathrm{~F}($ apwd9) $=1,595 \mathrm{~F}($ apwd10)=0,858 $\mathrm{F}(\operatorname{apwd1} 1)=0,844 \mathrm{df}=3,76 \mathrm{p}<0,05$

\begin{tabular}{|c|l|l|l|l|l|}
\hline \multicolumn{7}{|l|}{ PPW } & \multicolumn{3}{|l|}{$\begin{array}{l}\text { Saprinus } \\
\text { caerulescens }\end{array}$} & $5,08 \pm 0,26 \mathrm{a}$ & $4,58 \pm 0,33 \mathrm{a}$ & $4,73 \pm 0,47 \mathrm{a}$ & $4,35 \pm 0,60 \mathrm{a}$ \\
\cline { 2 - 6 } & $\begin{array}{l}\text { Saprinus } \\
\text { planiusculus }\end{array}$ & $3,63 \pm 0,31 \mathrm{~b}$ & $3,82 \pm 0,46 \mathrm{~b}$ & $3,28 \pm 0,29 \mathrm{~b}$ & $3,57 \pm 0,27 \mathrm{~b}$ \\
\cline { 2 - 6 } & Saprinus semistriatus & $2,97 \pm 0,34 \mathrm{c}$ & $3,25 \pm 0,32 \mathrm{c}$ & $3,08 \pm 0,28 \mathrm{~b}$ & $3,04 \pm 0,64 \mathrm{bc}$ \\
\cline { 2 - 6 } & $\begin{array}{l}\text { Saprinus } \\
\text { subnitescens }\end{array}$ & $3,22 \pm 0,47 \mathrm{bc}$ & $2,83 \pm 0,17 \mathrm{~d}$ & $2,98 \pm 0,28 \mathrm{~b}$ & $2,79 \pm 0,24 \mathrm{c}$ \\
\hline
\end{tabular}

$\mathrm{F}(\mathrm{ppwd} 8)=1,470 \mathrm{~F}(\mathrm{ppwd} 9)=2,031 \mathrm{~F}(\mathrm{ppwd} 10)=1,178 \mathrm{~F}(\mathrm{ppwd} 11)=4,177 \mathrm{df}=3,76 \mathrm{p}<0,05$

\begin{tabular}{|c|c|c|c|c|c|}
\hline \multicolumn{6}{|l|}{ PEL } \\
\hline \multirow{5}{*}{ 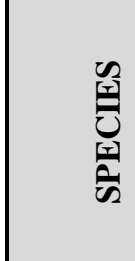 } & Saprinus caerulescens & & & & \\
\hline & & $6,28 \pm 0,38 a$ & $5,88 \pm 0,40 a$ & $5,87 \pm 0,67 a$ & $5,17 \pm 0,58 \mathrm{a}$ \\
\hline & Saprinus planiusculus & $4,43 \pm 0,22 b$ & $4,60 \pm 0,43 b$ & $4,17 \pm 0,46 b$ & $4,45 \pm 0,43 b$ \\
\hline & Saprinus semistriatus & $3,61 \pm 0,36 \mathrm{c}$ & $4,10 \pm 0,43 c$ & $3,68 \pm 0,32 b$ & $3,82 \pm 0,56 c$ \\
\hline & Saprinus subnitescens & $4,07 \pm 0,58 b c$ & $3,66 \pm 0,26 \mathrm{c}$ & $3,84 \pm 0,34 b$ & $3,61 \pm 0,35 c$ \\
\hline
\end{tabular}

$\mathrm{F}($ peld 8$)=2,337 \mathrm{~F}($ peld9 $)=1,055 \mathrm{~F}($ peld10 $)=2,734 \mathrm{~F}($ peld11 $)=0,600 \mathrm{df}=3,76 \mathrm{p}<0,05$

EL

\begin{tabular}{|c|c|c|c|c|c|}
\hline \multirow{4}{*}{ 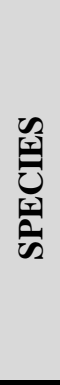 } & $\begin{array}{l}\text { Saprinus } \\
\text { caerulescens }\end{array}$ & $3,72 \pm 0,67 a$ & $3,10 \pm 0,23 a$ & $3,06 \pm 0,39 a$ & $2,86 \pm 0,37 \mathrm{a}$ \\
\hline & $\begin{array}{l}\text { Saprinus } \\
\text { planiusculus }\end{array}$ & $2,52 \pm 0,16 b$ & $2,71 \pm 0,29 b$ & $2,44 \pm 0,24 a$ & $2,56 \pm 0,15 a$ \\
\hline & $\begin{array}{l}\text { Saprinus } \\
\text { semistriatus }\end{array}$ & $2,08 \pm 0,22 b$ & $2,14 \pm 0,24 c$ & $2,18 \pm 0,15 a$ & $2,09 \pm 0,36 b$ \\
\hline & $\begin{array}{l}\text { Saprinus } \\
\text { subnitescens }\end{array}$ & $2,24 \pm 0,33 b$ & $1,99 \pm 0,17 \mathrm{c}$ & $5,00 \pm 0,47 \mathrm{a}$ & $1,94 \pm 0,17 b$ \\
\hline
\end{tabular}

$\mathrm{F}($ eld 8$)=1,574 \mathrm{~F}($ eld 9$)=0,835 \mathrm{~F}($ eld 10$)=4,677 \mathrm{~F}($ eld 11$)=3,245 \mathrm{df}=3,76 \mathrm{p}<0,05$

EW

\begin{tabular}{|l|l|l|l|l|l|} 
& $\begin{array}{l}\text { Saprinus } \\
\text { caerulescens }\end{array}$ & $5,36 \pm 0,33 \mathrm{a}$ & $3,77 \pm 0,16 \mathrm{a}$ & $3,28 \pm 0,32 \mathrm{a}$ & $3,54 \pm 0,55 \mathrm{a}$ \\
\hline $\begin{array}{l}\text { Saprinus } \\
\text { planiusculus }\end{array}$ & $5,0 \pm 0,32 \mathrm{~b}$ & $4,09 \pm 0,39 \mathrm{~b}$ & $3,52 \pm 0,33 \mathrm{~b}$ & $3,13 \pm 0,18 \mathrm{~b}$ \\
\hline $\begin{array}{l}\text { Saprinus } \\
\text { Semistriatus }\end{array}$ & $5,0 \pm 0,59 \mathrm{c}$ & $4,0 \pm 0,1,0 \mathrm{c}$ & $3,5 \pm 0,29 \mathrm{bc}$ & $3,2 \pm 0,18 \mathrm{bc}$ \\
\cline { 2 - 4 } & $\begin{array}{l}\text { Saprinus } \\
\text { subnitescens }\end{array}$ & $4,7 \pm 0,57 \mathrm{bc}$ & $4,11 \pm 0,26 \mathrm{~d}$ & $3,34 \pm 0,62 \mathrm{c}$ & $3,04 \pm 0,24 \mathrm{c}$ \\
\hline
\end{tabular}


Table 2. Continued

\begin{tabular}{|c|c|c|c|c|c|}
\hline \multicolumn{6}{|c|}{$\mathrm{F}(\mathrm{ewd} 8)=2,875 \mathrm{~F}(\mathrm{ewd} 9)=1,694 \mathrm{~F}(\mathrm{ewd} 10)=1,239 \mathrm{~F}(\mathrm{ewd} 11)=3,970 \mathrm{df}=3,76 \mathrm{p}<0,05$} \\
\hline \multicolumn{6}{|c|}{\begin{tabular}{|l|l|} 
PW & \\
\end{tabular}} \\
\hline \multirow{4}{*}{ 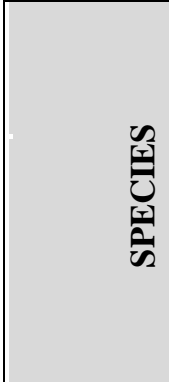 } & $\begin{array}{l}\text { Saprinus } \\
\text { caerulescens }\end{array}$ & $3,57 \pm 0,35 \mathrm{a}$ & $3,22 \pm 0,32 \mathrm{a}$ & $3,15 \pm 0,52 \mathrm{a}$ & $2,95 \pm 0,41 \mathrm{a}$ \\
\hline & $\begin{array}{l}\text { Saprinus } \\
\text { planiusculus }\end{array}$ & $2,53 \pm 0,18 b$ & $2,66 \pm 0,35 b$ & $2,33 \pm 0,16 b$ & $2,47 \pm 0,25 b$ \\
\hline & $\begin{array}{l}\text { Saprinus } \\
\text { semistriatus }\end{array}$ & $2,03 \pm 0,25 \mathrm{c}$ & $2,18 \pm 0,30 \mathrm{c}$ & $2,13 \pm 0,21 b c$ & $2,05 \pm 0,45 \mathrm{c}$ \\
\hline & \begin{tabular}{|l|} 
Saprinus \\
subnitescens
\end{tabular} & $2,31 \pm 0,40 \mathrm{bc}$ & $1,78 \pm 0,14 \mathrm{~d}$ & $1,81 \pm 0,22 \mathrm{c}$ & $1,84 \pm 0,19 c$ \\
\hline
\end{tabular}

$\mathrm{F}(\mathrm{pwd} 8)=2,104 \mathrm{~F}(\mathrm{pwd} 9)=1,880 \mathrm{~F}(\mathrm{pwd} 10)=1,531 \mathrm{~F}(\mathrm{pwd} 11)=3,014 \mathrm{df}=3,76 \mathrm{p}<0,0$

ween the biological parameter data of the species shown with different letters (a-d) in the same column. (Anova, Tukey).

The four Saprinus species were evaluated inter-specific and intra-specific differences. The analyses of variance (ANOVA) showed a significant difference. Statistical comparisons of morphometric analyzes of six characters for each species display that all characters differ each except Saprinus subnitescens Bickhardt, 1909 of PEL (P: 0,063). Interspecies comparison of the lengths of biometric parameters also shows significant differences which is the most important data, supported the present study. All data varies between species and this is the a fortiori analysis for our work $(\mathrm{P}<0.05)$ and $F$ values followed by $F(A P W)=3,993 \quad F(P P W)=4,204 \quad F(P E L)=7,817 \quad F(E L)=7,090 F(E W)=3,191$ $\mathrm{F}(\mathrm{PW})=4,050 \mathrm{df}=3,76$. Measurement of the biometric characters within the same species found in different months was also compared. However, APW of only D10 is different in all species while D8, D9, and D11 of Saprinus semistriatus and Saprinus subnitescens do not Show any differences. PPW shows differences in only D9 and for Saprinus semistriatus and Saprinus subnitescens, there was no significant D8, D10, and D11. Saprinus caerulescens was the only different species with measurements of PEL. For EL; Saprinus caerulescens in D8 show a great variability within the species while D10 does not include any differences. The EW measurements of the species were statistically different in D9. The biological parameter data of PW in D9 displays an important variation between other measurements in species.

Biometrical characters of four different species of necrophilous beetles (Histeridae) were successfully measured and analyzed by their morphological characters. In our study, the statistical differences were obtained as a result of the study; In fact, it reveals the importance of biometric morphometric analyses in preventing errors that may arise in species identification. Consistent with the literature, this research found that participants who reported using geometric morphometry also. Zhang et al. [16]; found significant morphological differences in the pronotum or elytron between any two Lucanidae subfamilies based on geometric morphometric analysis. Their study provides insights into the morphological variations and evolutionary history of the pronotum and elytron in four subfamilies of stag beetles. Our results corroborate a great deal of the previous work in Iran; geometric morphometric study of the genus Erodiontes (Coleoptera: Tenebrionidae) populations of E. pfaundleri showed significant differences in pronotum size whereas it was similar in size in populations of E. aelleni [17]. In another study, while dealing with the morphological effects of geographic distance on different populations [18]. Li et al. [19] studied six different biotypes of 4th instar nymphs in a Hemiptera species, based on the length differences and weights in their taxonomic characters. Increased attention to geometric morphometry contributes reliability to species identification so that this study corroborates these earlier findings.

Saprinus is the necrophilous genus that is the colonizer on the corpses and is helpful to calculate time after death [10]. The four species belonging to the Saprinus genus studied are the most heavily colonized individuals on the corpse in forensic studies and the most intensively colonized periodically $[8,9,10]$. These colonizers are using to determine the time of death according to their correct identification. The species may be affected by longitude, latitude, climate condition, and geographical environment of different provinces. The taxonomic characters used on the members of the Histeridae family guide by comparing the individuals in the identification keys. When differentiating between the two species in the identification keys, it was seen that individuals could not be considered individually, and they were diagnosed by comparing them with other species. The taxonomic characters used to differ the species in the keys by using 'more or less', 'usually', 'may be' [14]. However, the taxonomic characters used vary according to age, environmental conditions, and feeding environments. Therefore, our study supported other studies that the difficulties seen in the identification keys of the studied family can be solved by using morphometric methods. The taxonomic characters used to distinguish between species may differ according to age and environment, and these taxonomic characters cause problems in identification keys. Polat \& Öcal [20] indicated that some species can be defined as the 
same or inaccurate if they are identified by using conventional methods. As a result of the study, it has been proven that the biometric characters can be used in the identification keys via conventional methods.

\section{Acknowledgements}

This study was supported by Anadolu University Project Office (Project number: 1204F072).

\section{References}

[1] Mazur, S. (2011). A Concise catalogue of the Histeridae (Insecta: Coleoptera). Warsaw: Warsaw University of Life Sciences, SGGW Press.

[2] Caterino, M. S., \& Tishenchkin, A. K. (2014). New genera and species of Neotropical Exosternini (Coleoptera: Histeridae). ZooKeys(381), 11-78.

[3] Lackner, T. (2015). Coleoptera: Sphaeritidae, Histeridae. Folia Heyrovskyana, Series B(23), 1-33.

[4] Zhou, Y. L., Caterino, M. S., Ren, D., \& Slipinski, A. (2020). Phylogeny and evolution of Mesozoic and extant lineages of Histeridae (Coleoptera), with discovery of a new subfamily Antigracilinae from the Lower Cretaceous. Cladistics, 36(5), 521-539.

[5] Fincher, G. T. (1995). Predation on the horn fly by Hister Bruchi. Southwestern Entomologist, 20(4), $423-427$.

[6] Summerlin, J. W., Roth, J. P., \& Fincher, G. T. (1991). Predation by two species of Histerid Beetles on the Horn Fly. Southwestern Entomologist, 16(1), 45-49.

[7] Caneparo, M. C., Fischer, M. L., \& Almeida, L. M. (2017). Effect of temperature on the life cycle of Euspilotus azureus (Coleoptera: Histeridae), a predator of forensic importance. Florida Entomologist, 100(4), 795-801.

[8] Szelecz, I., Feddern, N., Seppey, C. W., Amendt, J., \& Mitchell, E. D. (2018). The importance of Saprinus semistriatus (Coleoptera: Histeridae) for estimating the minimum post-mortem interval. Legal Medicine(30), 2127.

[9] Özdemir, S., \& Sert, O. (2009). Determination of Coleoptera fauna on carcasses in Ankara province, Turkey. Forensic Science International(183), 24-32.

[10] Altunsoy, F., Turan, Y., Firat, S., \& Sert, O. (2017). Differences in succession of Coleoptera species attracted to pig carcasses in rural and urban habitats in Eskişehir Province, Turkey. Turkish Journal of Entomology, 41(2), $177-195$

[11] Lackner, T. (2010). Review of the Palaearctic genera of Saprininae (Coleoptera: Histeridae). Acta Entomologica Musei Nationalis Pragae, 50(1), 1-254.

[12] Secchi, F. (2002, February 18). July 2021 tarihinde http://www.insecte.org/photos/archives/histeridae_Secchi.pdf adresinden alınd

[13] Krikken, J., \& Huijbregts, J. (2001). Insects as forensic informants: the Dutch experience and procedure. Entomologia Experimentalis et Applicata(12), 159-164.

[14] Salman, S., Garrouste, R., Nel, A., \& Azar, D. (2018). The community succession of arthropods on a pig carcass in Lebanon: different taxonomic level approaches with faunistic notes. Annales de la Société entomologique de France, 54(5), 417-433.

[15] Ohara, M. (1994). A revision of the superfamily Histeroidea of Japan (Coleoptera). Insecta Matsumurana(51), 1238.

[16] Zhang, M., Ruan, Y., Wan, X., Tong, Y., Yang, X., \& Bai, M. (2019). Geometric morphometric analysis of the pronotum and elytron in stag beetles: insight into its diversity and evolution. ZooKeys(833), 21-40.

[17] Taratavi, S., Darvish, J., \& Mirshamsi, O. (2009). Geometric morphometric study of two species of the psammophilous genus Erodiontes (Coleoptera: Tenebrionidae) from the Lute desert, Central Iran. Iranian Journal of Animal Biosystematics, 5(2), 81-89.

[18] Albert, P., Moureau, B., Dommergues, J. L., \& David, B. (2001). Differentiation at a microgeographical scale within two species of ground beetle, Carabus auronitens and C. Nemoralis (Coleoptera, Carabidae): a geometrical morphometric approach. Zoologica Scripta(30), 299-311.

[19] Lİ, J., Ba1, R., Li, X., Jiang, J., \& Yan, F. (2013). Comparative Morphology and Morphometry of Six Biotypes of Bemisia tabaci (Hemiptera: Aleyrodidae) from China. Journal of Integrative Agriculture, 12(5), 846-852.

Polat, F., \& Çorak Öcal, İ. (2021). Phylogenetic analysis of Euscorpius phrygius Bonacina, 1980 (Scorpiones: Euscorpiidae) distributed in Turkey. . Biyolojik Çeşitlilik ve Koruma, 14(2), 214-219. 